\title{
New subsurface temperature maps for the Tertiary Lower Rhine Basin and the adjacent Variscan Basement - Germany, The Netherlands, Bel- gium
}

\author{
H. Karg ${ }^{1,2}$, C. Bücker ${ }^{3}$ \& R. Schellschmidt ${ }^{4}$ \\ ${ }^{1}$ Lehr- und Forschungsgebiet für Angewandte Geophysik, RWTH Aachen, Loch- \\ nerstrasse 4-20, 52064 Aachen, Deutschland. \\ Now: Wintershall Energía S.A., Maipú 757, Piso 7, C1006ACI Buenos Aires, Ar- \\ gentina; e-mail: harald.karg@wintershall.com.ar \\ ${ }^{3}$ RWE-DEA, Hamburg, Überseering 40, 22297 Hamburg \\ ${ }^{4}$ Institute of Joint Geoscientific Research (BGR-GGA), Stilleweg 2, 3055 Hannover \\ ${ }^{2}$ Corresponding author
}

Manuscript submitted: November 2004; accepted: April 2004

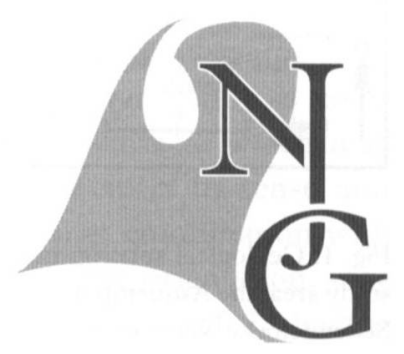

\begin{abstract}
The regional subsurface temperature field at the transition between the Palaeozoic Variscan Basement and the Cenozoic Lower Rhine Basin in Dutch, German and Belgium territories was mapped up to a depth of $1000 \mathrm{~m}$. Temperature data from 66 wells and 11 coal mine subcrops were available. In 46 wells, temperature logs, covering a cumulative depth interval of 6600 $\mathrm{m}$, were measured for this study.
\end{abstract}

Keywords: Lower Rhine Basin, Palaeozoic Basement, geothermal anomalies, isothermal maps, new temperature logs

\section{Introduction}

Where temperature data were scarce, temperature extrapolations to greater depths were made, using existing information of thermal rock properties, heat flow and geothermal gradients in the study area.

Thermal gradients within the Tertiary depocentres of the Lower Rhine Rift and the Palaeozoic basement highs are rather alike and generally do not exceed 22 ${ }^{\circ} \mathrm{C} / \mathrm{km}$. The unconformity between the Tertiary and the underlying coal-bearing Upper Carboniferous represents a thermal discontinuity. Geothermal gradients within the Upper Carboniferous average 45-50 ${ }^{\circ} \mathrm{C} / \mathrm{km}$ and are explained by the low permeabilities and the heat storage effect of dispersed organic matter and coal.

In zones of rapid downward water flux, related to karstified Devonian limestone provinces, and within the highly permeable pile of low-consolidated rocks of the Tertiary Lower Rhine Basin locally even negative thermal gradients were observed. The highest measured vertical thermal gradients of up to $67^{\circ} \mathrm{C} / \mathrm{km}$ are related to a depth interval of $300 \mathrm{~m}$ to $500 \mathrm{~m}$ here, also exhibiting the most pronounced lateral temperature differences. Positive thermal anomalies are explained by the occurrence of major faults, connecting the basement with the Cenozoic sediment fill and bounding individual Tertiary depocenters in the Lower Rhine Basin.

Isothermal maps at depths of $100 \mathrm{~m}, 300 \mathrm{~m}, 500$ $\mathrm{m}$ and $1000 \mathrm{~m}$ are calculated. The average detected and extrapolated temperatures are $11{ }^{\circ} \mathrm{C}(100 \mathrm{~m})$, $18^{\circ} \mathrm{C}(300 \mathrm{~m}), 27^{\circ} \mathrm{C}(500 \mathrm{~m})$ and $33^{\circ} \mathrm{C}(1000 \mathrm{~m})$. Temperature mapping revealed that the subsurface thermal structure closely corresponds to main tectonic features. The most prominent ones are hot springs in Chaudfontaine/Belgium and Aachen/Germany, associated with the occurrence of major thrusts at the former Variscan orogenic front. Other positive geothermal anomalies are related to block-faulting within the Lower Rhine Rift Basin and were detected by temperature measurements at the borders of the Tertiary Basin and its sub-basins. Depocentres of the Rur- and the Erft sub-basins and Paleozoic Highs of 
the Variscan Basement represent geothermal cooler areas. Temperatures at deeper levels $(1000 \mathrm{~m})$, below the Mesozoic/Cenozoic unconformity, are assumed to be governed by thermal characteristics of different lithologies, whereas the thermal effect of circulating groundwater at that level is considered unlikely.

\section{Geological Setting}

The study area has a triangular shape and is located in Belgium, the Netherlands and Germany and covers an area of nearly $5000 \mathrm{~km}^{2}$ (Fig.1).

The regional geology is dominated by the Lower
Rhine Basin, a rift structure, which has developed upon pre-existing basins of Carboniferous and TriassicJurassic age, extending about $100 \mathrm{~km}$ in length and 50 $\mathrm{km}$ in width. During the Neogene basin subsidence developed due to rifting, punctuated by phases of uplift and erosion. Subsidence of individual blocks was heterogeneous and was governed by NW-SE oriented faults, which cut into the north-western margin of the Rhenish Massif (Fig. 1); e.g. the central Erft Block subsided $1300 \mathrm{~m}$ and the Peel Block in the Netherlands $2000 \mathrm{~m}$ (Spelter, 1978, Klett et al., 2002). From west to east the Feldbiss, Rur and Erft faults separate the individual eastward dipping blocks. (Figs $1 \& 2$ ).

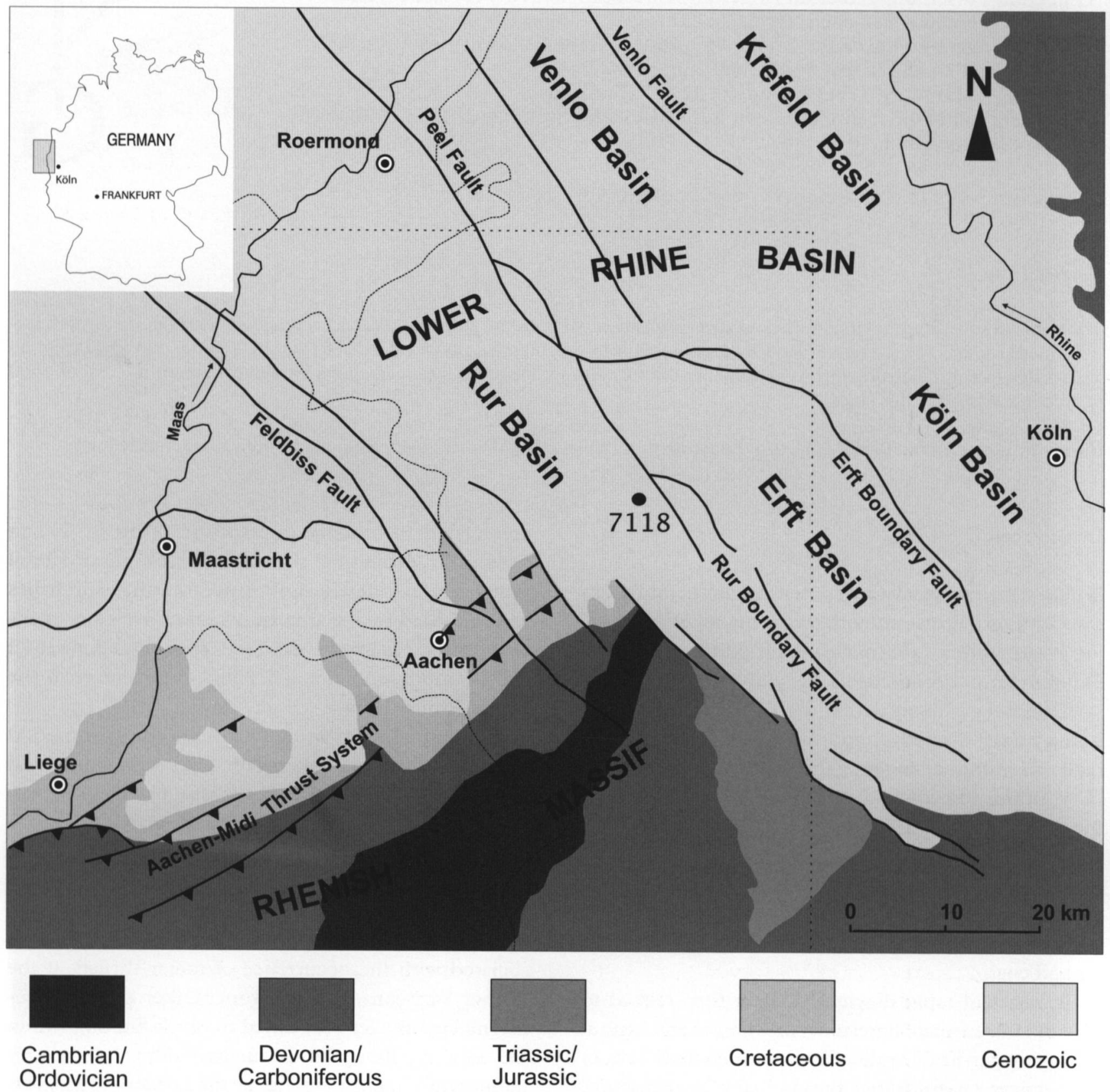

Fig. 1. Geologic map of the Lower Rhine Basin and adjacent areas. For the Lower Rhine Basin the most important structural elements and sub-basins are shown. 


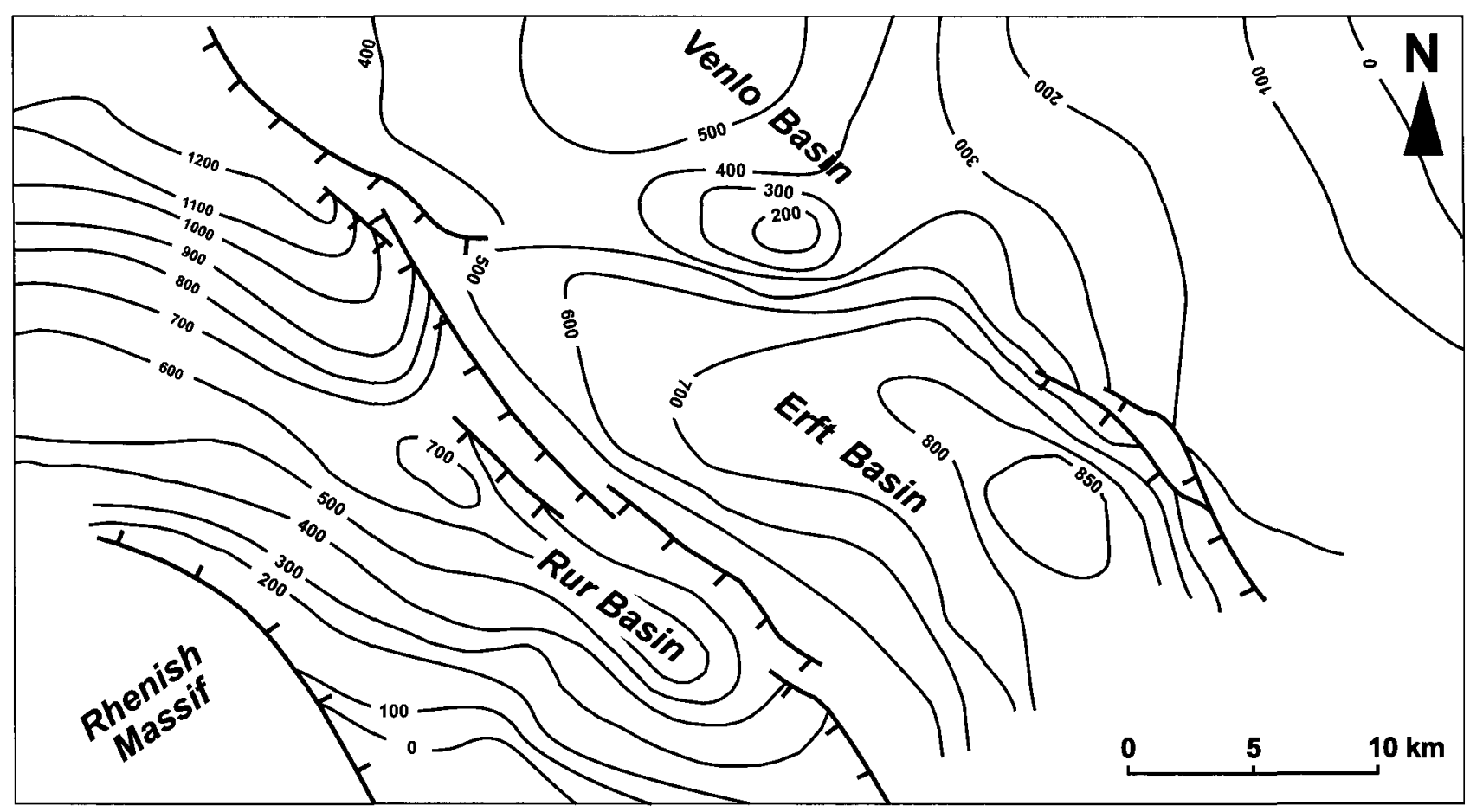

Fig. 2. Base Tertiary depth map for the Lower Rhine Basin, as derived from well results and gravimetry (modified after Dürbaum \& Wolf, 1958).

The entire rift structure of the Lower Rhine Basin is bordered by Devonian and Carboniferous rocks, forming the Variscan Basement (Rhenish Massif) in the southwest and the northeast. Variscan deformation shows a trend perpendicular to the overlying Cenozoic structures. Permian and Triassic rocks are also locally preserved beneath the Tertiary graben systems.

For the understanding of the subsurface thermal field, geologic and tectonic features at the transition from Variscan basement to the Cenozoic rift basin and the internal rift geometry play an important role.

\section{Previous thermal data - A review}

The earliest subsurface temperature measurements recorded in the study area were conducted as isolated rock temperature determinations in hard coal mining districts of the South Limburg and the Peel region in the Netherlands (De Braaf \& Maas, 1952, Sadée, 1975). De Braaf \& Maas (1952) found that thermal gradients within Upper Carboniferous strata average $40^{\circ} \mathrm{C} / \mathrm{km}$, whereas within the Cenozoic sedimentary cover lower gradients of $21^{\circ} \mathrm{C} / \mathrm{km}$ occur. Similar observations were made by Stuffken \& Arts (1965, in Visser, 1978) from 56 subsurface temperature determinations within Upper Carboniferous rock units. They found thermal gradients of $20^{\circ} \mathrm{C} / \mathrm{km}$ and 38 ${ }^{\circ} \mathrm{C} / \mathrm{km}$ within the Cenozoic cover and the Upper Carboniferous respectively. More recent thermal data from the German coal district revealed similar temperature gradients between 44 and $50^{\circ} \mathrm{C} / \mathrm{km}$ (Mücke, 1986; unpublished) within the coal bearing Upper Carboniferous section, being very similar to the Dutch data. The difference in the thermal regimes between the Cenozoic cover and the underlying Palaeozoic is usually explained by a thermal blanketing effect caused by lower thermal conductivities of coal bearing strata. Lower thermal conductivities are usually observed in more recently deposited, high porous Tertiary sediments. As a result of low conductivity the surface heat flow is reduced, causing a warming effect in underlying sediments. The same observation is made by Van Balen et al. (2002) in wells of the Roer Valley Graben in the Netherlands.

The first comprehensive analysis of the subsurface temperature field in the southern Netherlands was published by Van Dalfsen (1981). Based on temperature logs from the Echt, Sittard, Vlodrop, Susteren and Mheer geothermal wells he constructed isothermal maps to a depth of $250 \mathrm{~m}$. The maps show a laterally homogenous thermal field with temperatures between 14 and $16^{\circ} \mathrm{C}$ at a depth of $250 \mathrm{~m}$.

For the Belgium territory, Legrand (1975) published temperature data from the geothermal wells Soumagne, Chaudfontaine and Val Benoit, located at the northern flank of the London-Brabant Massif. They constructed isothermal maps, partly based on temperature extrapolations, to a depth of $3000 \mathrm{~m}$. A geothermal anomaly occurs at the Chaudfontaine loca- 
tion, a geothermal spring with surface water temperatures between $30^{\circ} \mathrm{C}$ and $36^{\circ} \mathrm{C}$. The elevated temperatures are explained by a rapidly circulating groundwater recharge and discharge system within Lower Carboniferous limestones (Graulich, 1983). Pommerening (1992) estimates circulation depths of 700 $\mathrm{m}$ in this area.

Temperature maps from Vandenberghe \& Fock (1989) show elevated geothermal gradients for the north-eastern part of Belgium. Temperatures in depths of $1000 \mathrm{~m}$ and $2000 \mathrm{~m}$ average $60^{\circ}$ and $90^{\circ}$ respectively. The interpretation of the geothermal anomaly, however, has to be done with a certain degree of caution as the maps rely on only few, and partly extrapolated data. Towards the central parts of Belgium subsurface temperatures appear to decrease. At a depth of $2000 \mathrm{~m}$ temperatures around $50^{\circ} \mathrm{C}$ are implied and are attributed to a rise of the Caledonian basement at shallow subsurface depths (Vandenberghe \& Fock, 1989).

A detailed geothermal study on a smaller regional scale was carried out by Pommerening (1992) in the city of Aachen, where Europes hottest geothermal springs with surface temperatures of more than $70^{\circ} \mathrm{C}$ occur. An analogue to the above mentioned Chaudfontaine well, Pommerening (1992) relates the presence of hot springs in Aachen to groundwater recharge and discharge processes along major thrust faults at the northern rim of the Rhenish Massif (Aachen-Midi thrust system). Temperature measurements in a shallow well in the vicinity of this thrust system proved temperatures of $40{ }^{\circ} \mathrm{C}$ at a depth of only $50 \mathrm{~m}$. Such temperature data, related to a highly disturbed thermal regime, were not used for isothermal mapping, as this study aims to portray the regional subsurface temperature field.

For the Northern Rhenish Massif, where the Palaeozoic basement crops out, only scarce subsurface temperature data exist due to a lack of exploratory and industrial wells. However, detailed geothermal data (temperature logs, heat conductivity determinations on rock samples, heat flow measurements) from the research borehole Konzen 1 at the southern flank of the Stavelot-Venn anticline (Fig. 1) were published by Schürmeyer et al. (1984). The well reached a depth of $400 \mathrm{~m}$. An average geothermal gradient of $22{ }^{\circ} \mathrm{C} / \mathrm{km}$ and a heat flow density of $72.2 \pm 0.3$ $\mathrm{mW} / \mathrm{m}^{2}$ was determined (Dornstaetter \& Sattel, 1985). The latter value is in good agreement with a regional heat flow density map, published by Haenel (1983) for the Rhenish Massif and is also in line with the mean heat flow of $76 \mathrm{~mW} / \mathrm{m}^{2}$ in the Netherlands (Ramaekers, 1991).

The majority of the thermal data used in this study was obtained from the southwestern Lower Rhine Basin, characterised by its thick infill of Cenozoic sediments. This area has undergone intensive lignite exploration during the last few decades and therefore contains a large number of exploration and groundwater observation wells drilled by RWERheinbraun. Balke (1973) was the first to systematically investigate the subsurface temperature field of this province and to publish subsurface temperature data and isothermal maps. His interpretation, however, is only related to the Cenozoic Graben systems and does not extend to the older Palaeozoic highs bounding the Tertiary Basin.

A recent contribution to the geothermal data base in the Lower Rhine Embayment was made by the Institute of Joint Geoscientific Research in Hannover. In the early 1990's they carried out detailed temperature logging in a large number of groundwater observation wells, most of them reaching depths of $550 \mathrm{~m}$.

The assessment of data quality for the previous thermal data is difficult as mostly no information of the applied measurement technique and in only a few cases relative errors were given. In some cases relative errors of \pm 0.1 to $0.01{ }^{\circ} \mathrm{C}$ were noted, which was regarded as reliable data quality. The least reliable data were considered the subsurface rock temperatures in German and Dutch coal mines, as usually no absolute or relative errors were given.

Continuous temperature logs from wells are in general considered most reliable. In all cases the temperature measurements were carried out several months or years after drilling so that effects of mud circulation could be ignored. Where thermal profiles exhibit marked effects of circulating groundwater, the data were not used for contouring isothermal maps.

For the wells Kastanjelaan, Heugem and Straeten-1 only bottom-hole-temperature data were available, without information on mud circulation times and data correction procedures were available. A deep well in the Roer Valley Graben is the Straeten-1 hydrocarbon exploration well, penetrating more than $1200 \mathrm{~m}$ of Tertiary sediments.

\section{Results}

\section{New temperature measurements and data statistics}

In order to enhance the present thermal data base for the study area systematic temperature logging in 46 wells, of which 24 wells are located within the Cenozoic fill of the Roer- and the Erft sub-basins, has been carried out (Fig. 1). The other 22 wells are located at the northern rim of the outcropping Variscan Basement and eight of them reach depths greater than 
$100 \mathrm{~m}$. The temperature measurements carried out in the individual wells cover a depth range from $50 \mathrm{~m}$ to more than $500 \mathrm{~m}$. For statistical analysis of the data and for contouring isothermal maps, it was decided to disregard wells shallower than $100 \mathrm{~m}$.

Altogether temperature logs with a cumulative depth of $6600 \mathrm{~m}$ were measured during various logging campaigns. The sampling interval during temperature logging was $0.2 \mathrm{~m}$ and the temperature probe was calibrated before each logging campaign. The absolute and relative measurement error was determined as $\pm 0.1^{\circ} \mathrm{C}$ and $\pm 0.02^{\circ} \mathrm{C}$ for a temperature interval between $-20^{\circ} \mathrm{C}$ and $+80^{\circ} \mathrm{C}$ respectively. The data were registered down-hole to guarantee a widely undisturbed water column in the borehole.

Including our new temperature measurements, a total of 66 wells ( 63 continuous temperature logs and 3 BHT data) and 95 individual temperature determinations in mining subcrops (covering a depth interval between $380 \mathrm{~m}$ and $875 \mathrm{~m}$ ) constitute the database of the presented study. The well data temperature and thermal gradient curves are plotted as a function of depth in Fig. 3a and b. Horizontal bars are indicative of lateral variations in the data at the respective depth interval. It is clear that the amount of data (number to the right of the variation bars) decreases steadily with depth and the number of wells deeper than $500 \mathrm{~m}$ becomes significantly scarce. Only 5 temperature data measurements are available at $1000 \mathrm{~m}$.

The maximum lateral temperature variations of $27^{\circ} \mathrm{C}$ are observed at a depth of $400 \mathrm{~m}$. Thermal gradients average between 20 and $30^{\circ} \mathrm{C} / \mathrm{km}$ in the study area. Beneath $500 \mathrm{~m}$ thermal gradients steadily decline to values of 1.5 to $3.0^{\circ} \mathrm{C} / 100 \mathrm{~m}$ over the area. These values typically represent the thermal situation of the Variscan consolidated crust bordering and underlying the Lower Rhine Rift Basin.

Analysis of the temperature logs has revealed that lithology and circulating groundwater in the subsurface of the Lower Rhine Rift Basin is the reason for the distinct thermal heterogeneity observed in the area. The Tertiary sedimentary infill is typically composed of thin consolidated intercalated shales, sands and coal measures, each of them differing in their characteristic thermal and petrophysical properties, such as heat conductivity, heat capacity, porosity and permeability, governing temperature distribution and hydrodynamic properties.

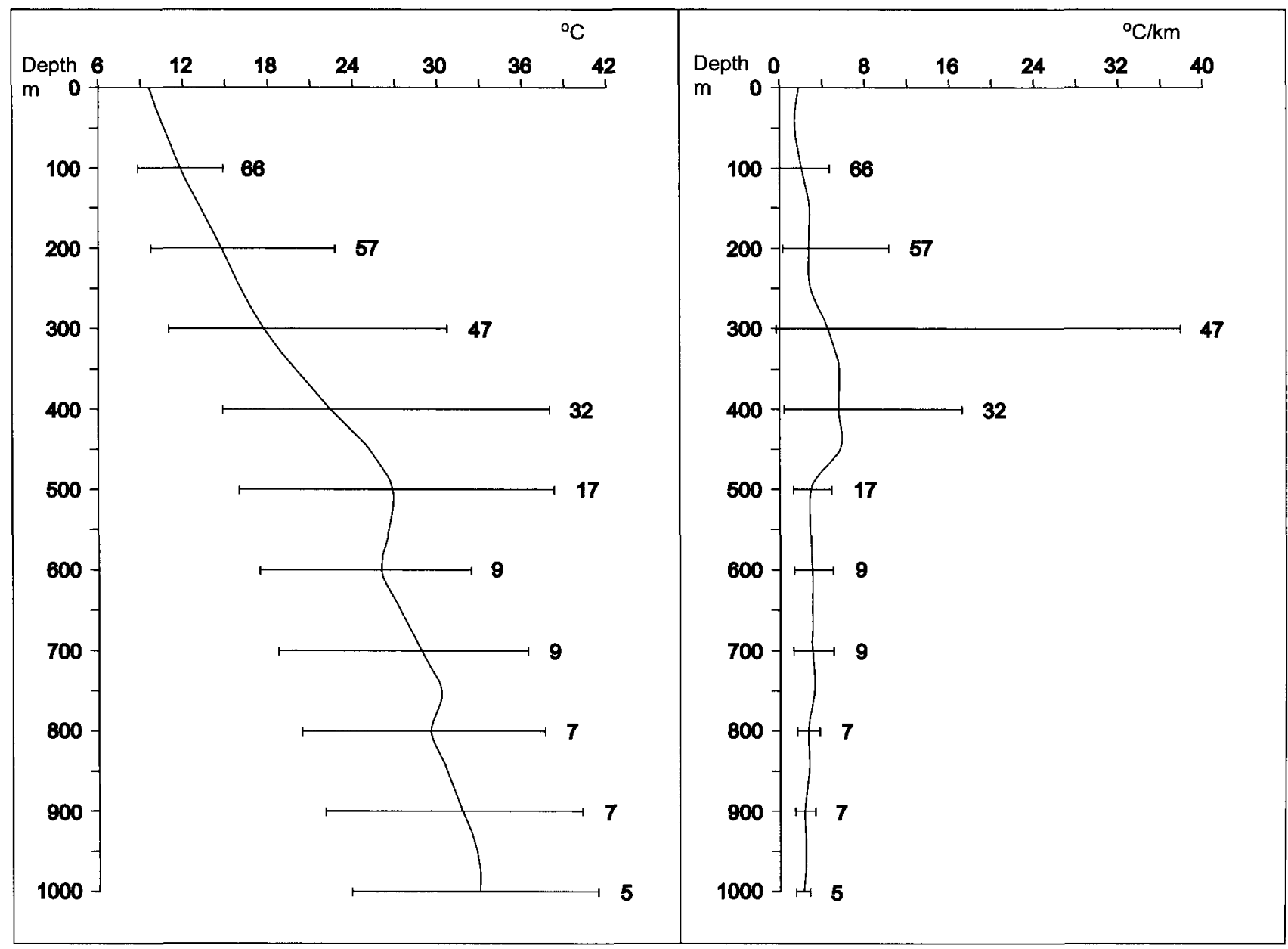

Fig. 3. Geothermal database of the study area. Curves show the average temperatures (left) and the average geothermal gradients (right) as function of depth. Horizontal bars are indicative of the data variability in the respective depth level. Numbers indicate amount of available data. 
Deep seated sub-vertical faults divide the basin into several sub-basins and are considered as pathways for groundwater, that is heated at the basin floor at depths around $1200 \mathrm{~m}$ to $1300 \mathrm{~m}$ and migrated upward until reaching an aquifer in a shallower level. An example for this mass-bounded heat transfer process is the well 7118 , situated close to the Rur boundary fault, separating the Roer- from the Erft sub-basin (Fig. 4). At a depth between $260 \mathrm{~m}$ and $290 \mathrm{~m}$ a strong positive heat anomaly was measured with a geothermal gradient up to $38^{\circ} \mathrm{C} / 100 \mathrm{~m}$ (Fig. 4). The interval with the anomalous high temperatures coincides with the occurrence of a sandy aquifer, which is sealed at the top and at the base by impermeable lignite measures. Secondary anomalies were observed in

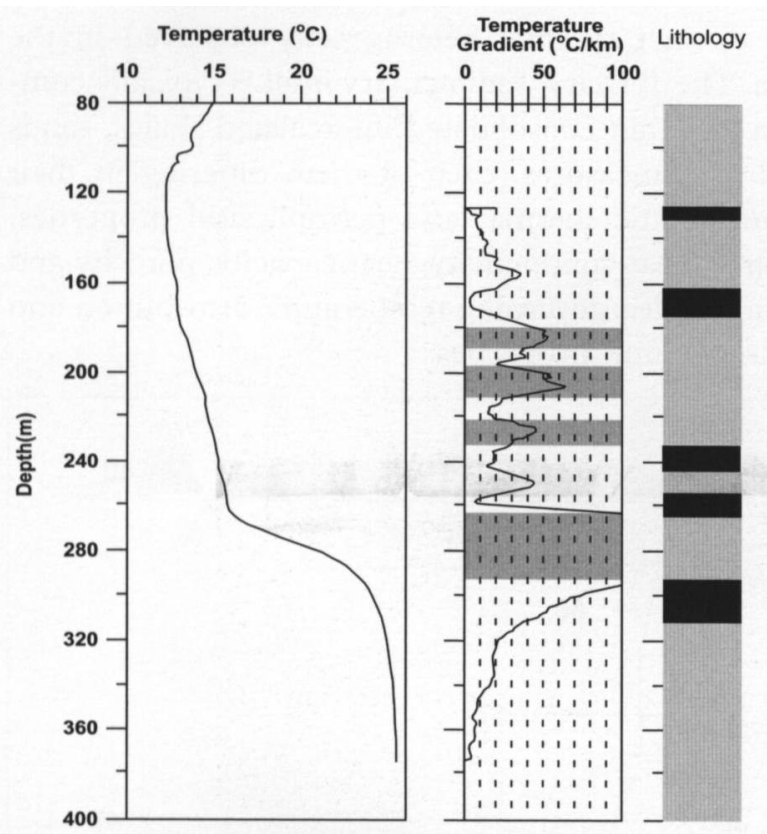

Fig. 4. Temperature log of the well 7118 (for location see Fig. 1). Note the influence of circulating groundwater in different sandy aquifer intervals (shaded in gray). Highest thermal gradients are observed at a depth between $270 \mathrm{~m}$ and $290 \mathrm{~m}$. Tertiary coal seams (black signature in lithology column to the right) act as aquicludes for the sandy aquifers (gray signature).

another aquifer at a higher stratigraphic position.

In other wells, the vertical mobility of groundwater even causes negative geothermal gradients, when cold water from shallow levels is rapidly recharged into the sedimentary sequence. Examples are found in the Lower Rhine Rift Basin in variable depths, as well as in karstified limestones from the Variscan Basement at depths up to $100 \mathrm{~m}$.

\section{Temperature extrapolations}

As data become scarce at depths greater than $500 \mathrm{~m}$ temperature data were mathematically extrapolated to assess the deeper thermal field. A high degree of uncertainty therefore has to be considered when interpreting the $1000 \mathrm{~m}$-isothermal map.

If parameters like thermal conductivity, heat production rate of the subsurface rocks and heat flow are known, it is possible to extrapolate temperature data to a given depth using a method proposed by Schulz \& Schellschmidt (1991). Instead of employing heat flow data for temperature extrapolations geothermal gradients for specific intervals can be used, provided appropriate information is available.

For the study area an average surface heat flow of $72 \mathrm{~mW} / \mathrm{m}^{2}$ was assumed, according to the work of Schürmeyer (1984). A number of heat flow values for the Tertiary Lower Rhine Rift Basin was published by Balke (1970) but these data exhibit strong variations due to arbitrary thermal conductivities of the waterfilled and highly porous Tertiary sediments. Thermal properties of poorly consolidated Tertiary rocks (gravel, sand, shale, lignite) were taken from Balke (1973), who determined an average value of $2.9 \mathrm{~W} / \mathrm{mK}$ for Tertiary water-saturated sands and gravels, the predominant lithology in the Lower Rhine Rift Basin. Thermal conductivity measurements for the Lower Palaeozoic basement were performed by Schürmeyer (1984) and revealed very similar values of 2.8-3.1 $\mathrm{W} / \mathrm{mK}$. The heat storage effect of organic matter and coal is important for the Upper Carboniferous. Low thermal conductivities of $1.8-2.2 \mathrm{~W} / \mathrm{mK}$, as determined by Mücke (1964), clearly explain the observed high thermal gradients, as published by Visser (1978).

For temperature extrapolations in wells within the Lower Rhine Rift Basin the Base Tertiary unconformity was considered as a thermal discontinuity. In general, lower geothermal gradients are observed within the Tertiary sediments than in the coal bearing, low-conductivity rocks of the Upper Carboniferous. The base Tertiary surface for each well location was determined using the map in Fig. 2 and for each corresponding well, temperatures below the Tertiary were calculated using an average geothermal gradient of $45^{\circ} \mathrm{C} / \mathrm{km}$, representative of the Carboniferous section.

It should be noted that the above described assumptions for temperature calculations do not take into account that the subsurface temperature field within the Tertiary basin fill is strongly influenced by heat convection and variable thermal conductivities in porous media and thus involves a major simplification.

\section{Temperature maps}

Continuous temperature logs, bottom-hole temperatures, and extrapolated temperature data were compiled from 66 wells and from about 90 individual subsurface temperature determinations in German and 
Dutch coal mines to construct isothermal maps for the study area.

Contouring of the isotherms was performed by using a software from the BGR/GGA in Hanover. As no topographic correction was applied to the data, all maps are referred to topographic surface level.

In this paper the temperature distribution in depths of $100 \mathrm{~m}, 300 \mathrm{~m}, 500 \mathrm{~m}$ and $1000 \mathrm{~m}$ are shown (Figs. 5-8). Isothermal lines were contoured at variable intervals, according to the density of available data. For the isothermal maps up to $300 \mathrm{~m}$ of depth, each isothermal line was contoured $\left(\Delta \mathrm{T}=1^{\circ} \mathrm{C}\right)$. For the $500 \mathrm{~m}$ isothermal map each $2{ }^{\circ} \mathrm{C}$ and for the $1000 \mathrm{~m}$ level each $4{ }^{\circ} \mathrm{C}$-line is plotted.

The major structural elements, as far as consid- ered relevant for the temperature distribution, and important geologic features, like the limit between the Variscan basement and the Tertiary Lower Rhine Rift Basin, are shown as overlay on each isothermal map.

As the rationale of this study was the compilation of a regional subsurface temperature field it should be noted that the isothermal maps have been biased in that the temperature anomalies caused by the Aachen hot springs were omitted. The latter are known to cause locally very pronounced thermal effects with surface temperatures of more than $70^{\circ} \mathrm{C}$.

\section{The $100 \mathrm{~m}$ isothermal map (Fig.5)}

Measured temperatures at the $100 \mathrm{~m}$ level oscillate between $8^{\circ} \mathrm{C}$ and $15^{\circ} \mathrm{C}$. Although this level exhibits

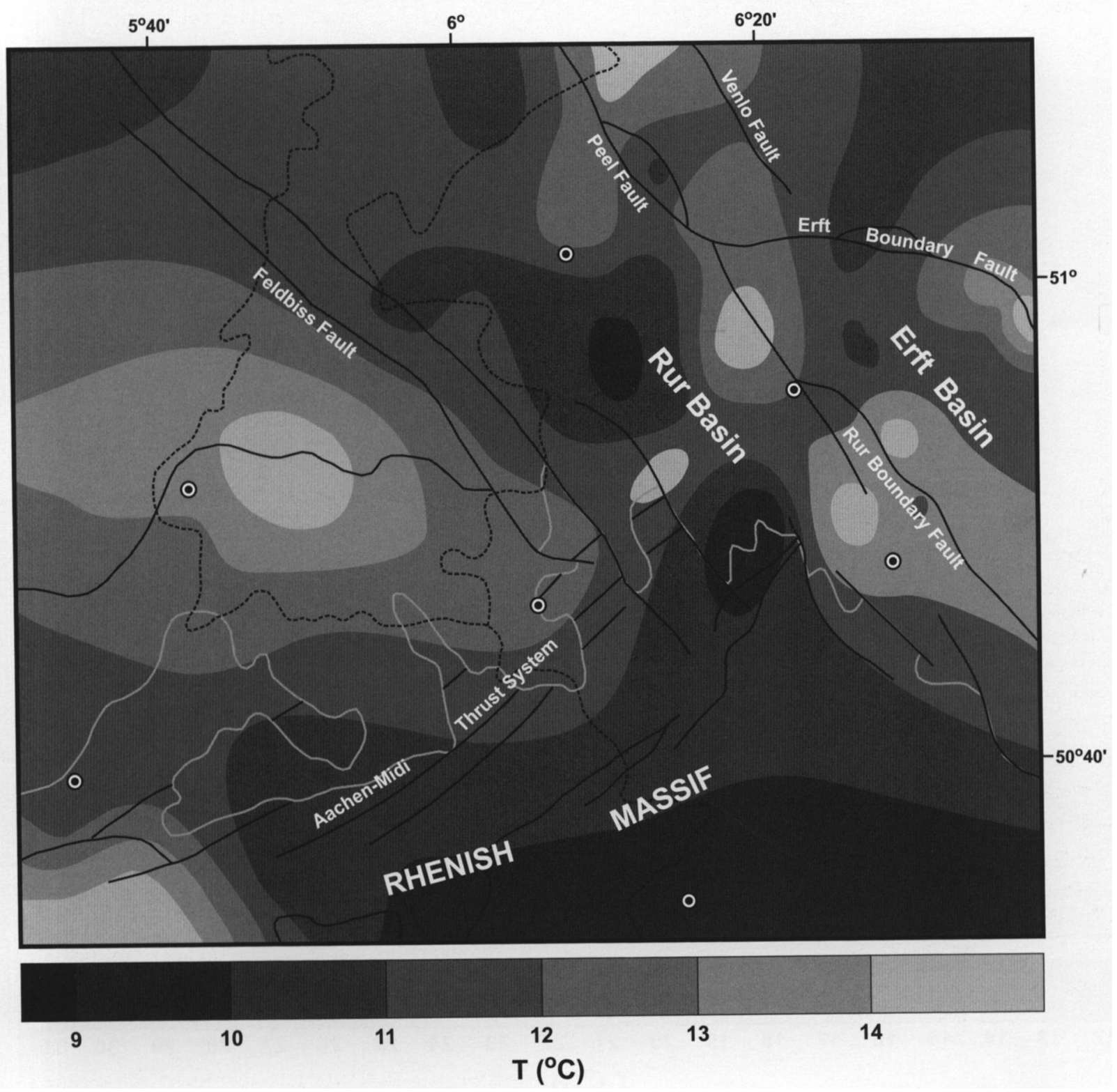

Fig. 5. Temperature distribution at $100 \mathrm{~m}$ depth. The dashed line indicates country borders. The limit between the Tertiary basin fill to the Paleozoic is marked by a continuous line. Major faults are labeled. Isothermal contours: $1^{\circ} \mathrm{C}$. 
only small lateral variations in temperature, a discrimination between warmer and colder domains can be made, which corresponds to important geologic features. Maximum temperatures are detected along the Roer- and the Peel Fault and in the vicinity of Maastricht. In contrast, in the southern part of the map, the lowest temperatures appear, where Palaeozoic rocks crop out.

\section{The 300 m isothermal map (Fig.6)}

At the $300 \mathrm{~m}$-level substantial lateral temperature variations of about $20^{\circ} \mathrm{C}$ are observed. The highest temperatures of up to $31^{\circ} \mathrm{C}$ appear in the southwest (close to Luettich, Belgium) and again at the tectonic boundary between the Roer and the Erft blocks. The depocentres of the Tertiary sub-basins continue to appear as low-temperature regions. This is presumably due to the effect of descending cold surface waters. Clear evidence for this mechanism of cooling is given in some wells, where a negative thermal gradient in certain depth intervals of some tens of metres was observed, evidencing locally strong groundwater fluxes. The Variscan Basement also show up as a geothermal cold area, best represented by the Konzen-1 well, where temperatures of $14{ }^{\circ} \mathrm{C}$ were measured at $300 \mathrm{~m}$.

A comparison of the map image with the statistical variations of geothermal gradients and temperatures (Fig. 3), implies that fault-related heat transport
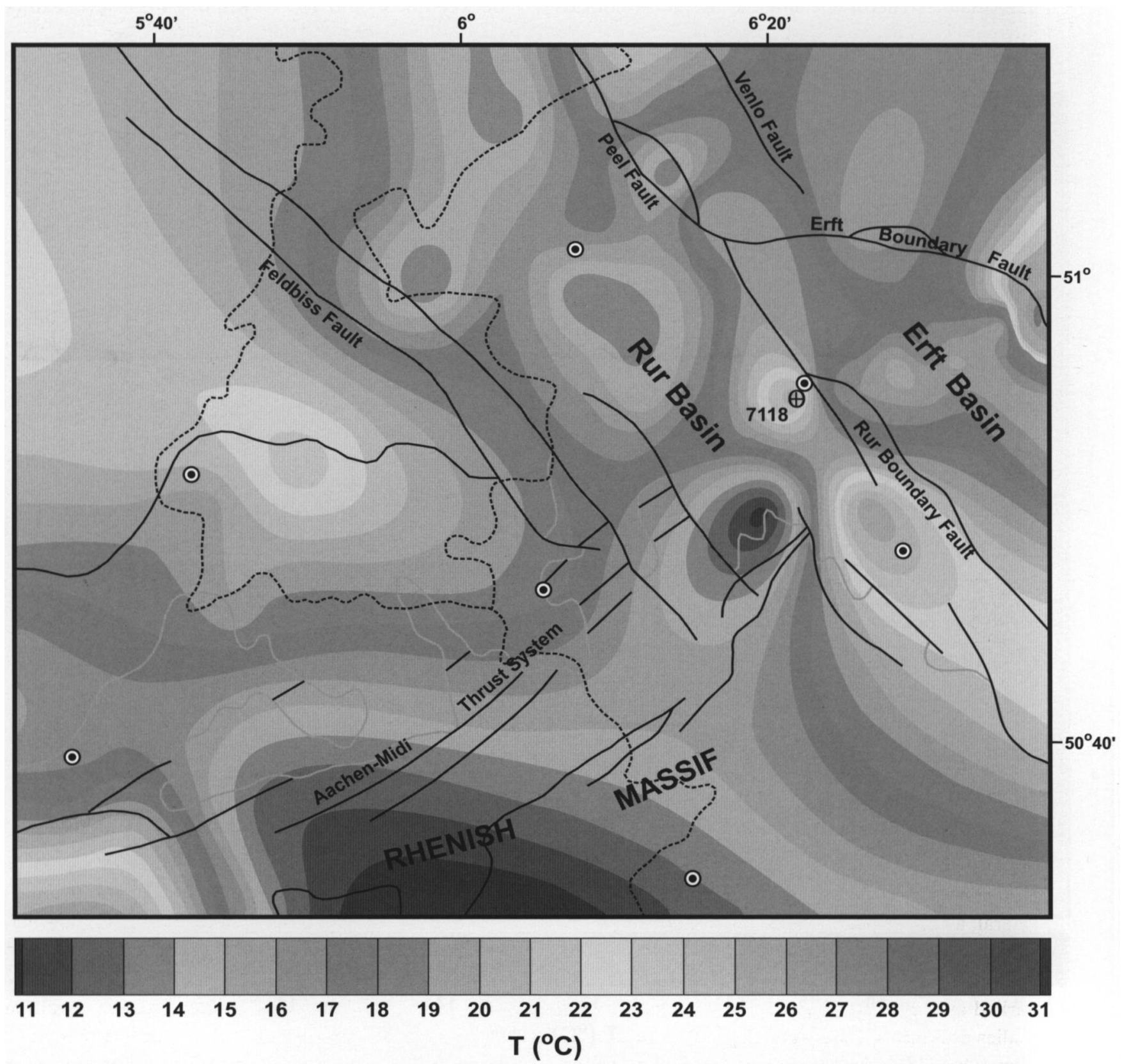

Fig. 6. Temperature distribution at $300 \mathrm{~m}$ depth. The location of well 7118 is indicated (for explanations see text). The dashed line indicates country borders. The limit between the Tertiary basin fill to the Paleozoic is marked by a continuous line. Major faults are labeled. Isothermal contours: $1^{\circ} \mathrm{C}$. 


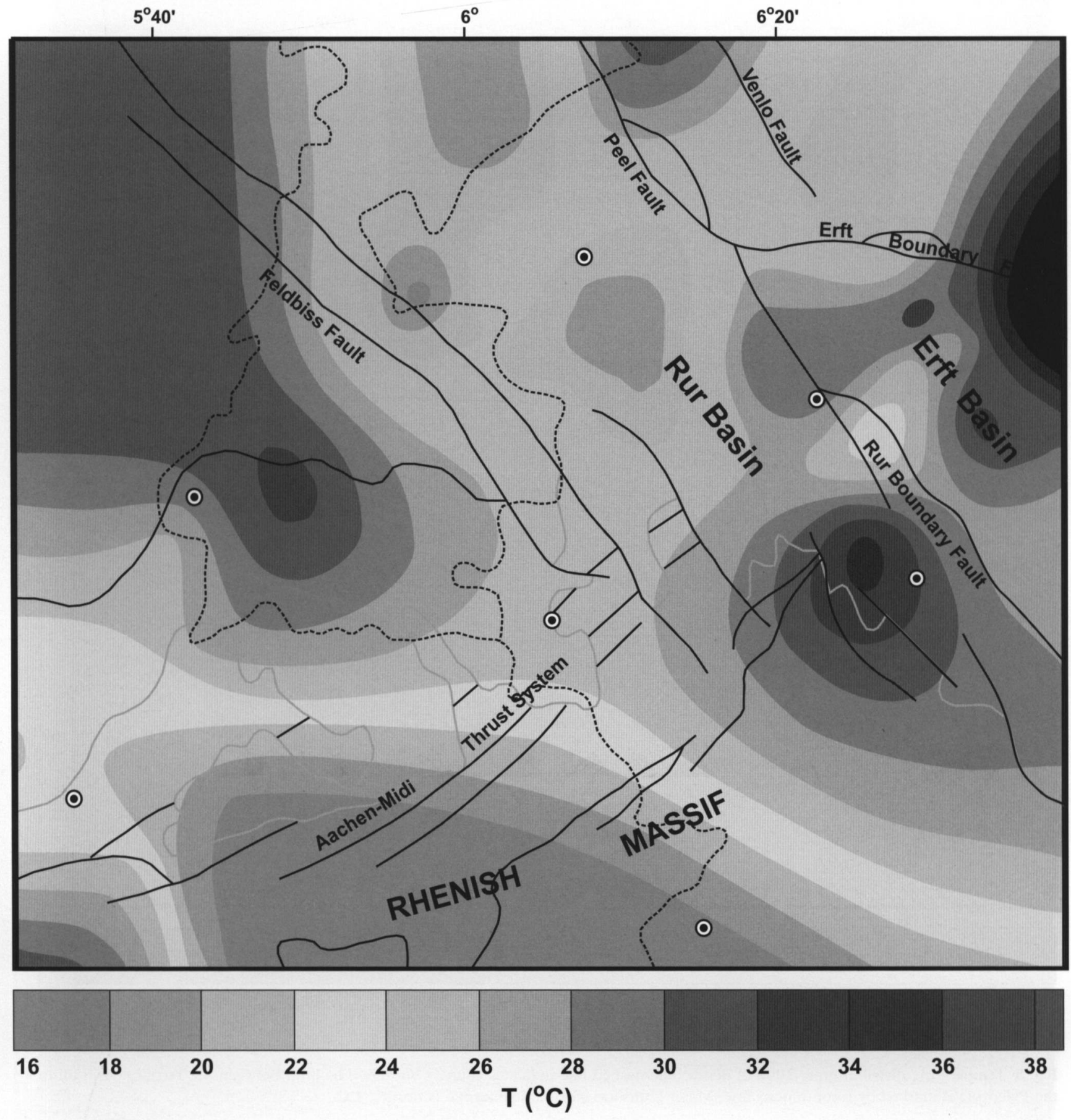

Fig. 7. Temperature distribution at $500 \mathrm{~m}$ depth. The dashed line indicates country borders. The limit between the Tertiary basin fill to the Paleozoic is marked by a continuous line. Major faults are labeled. Isothermal contours: $2^{\circ} \mathrm{C}$.

processes are very important at this depth level.

\section{The $500 m$ isothermal map (Fig.7)}

In general, a similar picture as described for shallower levels is represented by the $500 \mathrm{~m}$ isothermal map. The lateral temperature gradients at this level are not so marked and the boundaries of positive geothermal anomalies are not as sharp as at the $300 \mathrm{~m}$-level. This effect may be caused by the increasing thermal equilibration in deeper parts of the basin, due to less pronounced temperature gradients between descending and ascending groundwater. The most pronounced positive temperature anomalies are detected at the easternmost part of the study area and are related to the Erft boundary fault, where maximum temperatures up to $38^{\circ} \mathrm{C}$ were measured; and at the transition between pre-Tertiary rocks and the Tertiary Basin fill. The latter is related to the southwestern boundary faults of the Tertiary rift basin. The centres of the Roer and the Erft sub-basins are characterised by temperatures between $18{ }^{\circ} \mathrm{C}$ and $26^{\circ} \mathrm{C}$, which convert to average geothermal gradients of 18 to $34^{\circ} \mathrm{C} /$ 


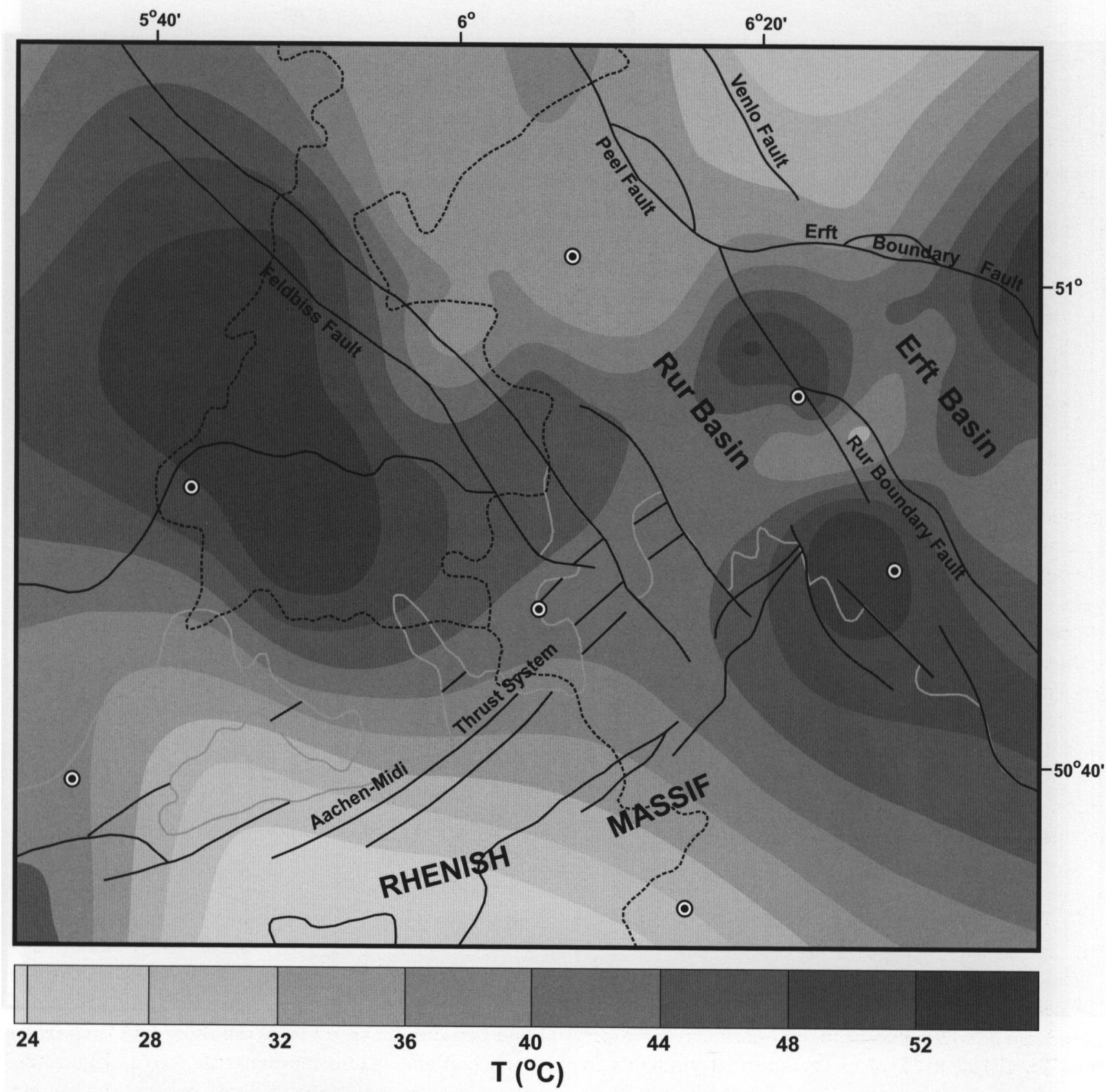

Fig. 8. Temperature distribution at $1000 \mathrm{~m}$ depth. The dashed line indicates country borders. The limit between the Tertiary basin fill to the Paleozoic is marked by a continuous line. Major faults are labeled. Isothermal contours: $4^{\circ} \mathrm{C}$.

$\mathrm{km}$. Similar thermal gradients are expected for the Paleozoic basement, however, no data for this depth are available.

\section{The 1000 m isothermal map (Fig.8)}

Five borehole data and deep temperature data from mining subcrops (up to $875 \mathrm{~m}$ ) were available at this depth. However, most of the data used to construct the isothermal contours result from temperature extrapolations using typical thermal gradients characteristic for the Tertiary and for the Palaeozoic Basement.

Between $500 \mathrm{~m}$ and $1000 \mathrm{~m}$ the lithologic inventory changes significantly as mostly Palaeozoic rocks are encountered at depths below $1000 \mathrm{~m}$. For Palaeozoic lithologies a thermal effect of circulating groundwater is ruled out due to low permeabilities. It was assumed that the temperature distribution at this depth is a result of basinal heat flow and heat conduction, and reflects the differences in thermal properties of the rocks.

In the $1000 \mathrm{~m}$ trend map an east-west oriented, central area of elevated temperatures $\left(40-52{ }^{\circ} \mathrm{C}\right)$ coincides with the distribution of low-conductive Upper Carboniferous rocks in the subsurface, as known from wells and mining activities. Lower temperatures $\left(<40^{\circ} \mathrm{C}\right)$ are calculated for the Lower Paleozoic basement in the south and for the northernmost parts of the study area (northern Erft Basin and southern Roer Valley Graben), where Tertiary sediments are 
thicker than $1000 \mathrm{~m}$ (Fig.2).

It should be stated again that the $1000 \mathrm{~m}$ isothermal map is the least data-constrained one and, apart from a few real measured temperature data points, it relies on data extrapolation. Therefore it should be referred to as a thermal trend map rather than an isothermal map. Even though for temperature calculations realistic geological assumptions have been made, the presented map was constructed only to visualise a likely state of the deep thermal field in the study area and does not claim absolute accuracy.

\section{Discussion and Conclusions}

Based on a recompilation of existing thermal data and new subsurface temperature measurements a more detailed picture of the subsurface temperature distribution in the Lower Rhine basin and the adjacent Variscan basement highs could be constructed. Temperatures and temperature gradients are typically influenced by the strongly variable thermal properties of highly compacted Paleozoic rocks and water-filled, low consolidated Tertiary sediments, by heat flow and by tectonic processes.

Regionally, the subsurface temperature field closely corresponds to the outline of typical geotectonic features, characterising the shape and architecture of the extensional Lower Rhine Basin. Within the basin, the temperature field $(100-500 \mathrm{~m})$ is strongly heterogeneous with clearly mappable thermal anomalies, in contrast to the Variscan Basement in the southwest. Maximum lateral temperature variations of up to $27^{\circ} \mathrm{C}$ were observed at a depth of $400 \mathrm{~m}$. Geothermal gradients along fault zones (Rur fault, Erft fault), limiting large tectonic blocks and sub-basins, reach more than $38^{\circ} \mathrm{C} / 100 \mathrm{~m}$. Typical geothermal gradients in depocentres vary between 18 and $34^{\circ} \mathrm{C} / \mathrm{km}$. Surface heat flows and thermal gradients in the extensional Tertiary Basin are reduced by descending groundwater. Within highly porous strata, geothermal gradients can decrease locally to zero or even to negative values. Temperature maps provided by Van Dalfsen (1981) show average temperatures of $12-16^{\circ} \mathrm{C}$ in a depth between 150 and $250 \mathrm{~m}$ for the South Limburg area in the Netherlands and thus fit very well to our data.

It can be discussed whether groundwater pumping around the browncoal mines causes thermal effects of a magnitude that they become visible in the isothermal maps. For this study, only groundwater observation wells and no active pumping wells have been used for temperature logging. Measurement locations were chosen to have a distance of several hundred meters to several kilometres away from active pumping wells to ensure that major distortion of the ther- mal field can widely be eliminated.

The deeper thermal field $(1000 \mathrm{~m})$ is assumed to be governed by heat conduction and by the thermal properties of different lithologies rather than by convective processes. Although, interpretation for this depth level suffers from a scarcity of measured data, there is some evidence for elevated temperatures in areas where coal bearing Upper Carboniferous rocks occur in the subsurface. This is explained by low thermal conductivities, which are characteristic of this rock type. Thermal blanketing processes, where surface heat flow is reduced by groundwater flow in highly porous media and consequently temperature gradients in underlying strata increase, may also occur.

The general trends shown in our maps correspond to deep subsurface temperature data recently published by Van Balen et al. (2002) for the Roer Valley and the Peel Block. Van Balen et al. (2002) provide a regional deep subsurface temperature map of the Netherlands at a depth of $2000 \mathrm{~m}$. Although these data do not allow identification of small scale thermal anomalies, it is interesting to mention that the depocentres of the Roer Valley Graben appear as lowtemperature zones, which is in good agreement with the trends shown in our maps.

\section{Acknowledgements}

We gratefully acknowledge STAWAG Energy Company/Aachen for financial funding and Prof. Dr. J. Wohlenberg for his support of this study. The presentation of isothermal maps would not have been possible without the support provided by Prof. C. Clauser and his working group from the BGR-GGA (Geowissenschaftliche Gemeinschaftsaufgaben), Hannover. We much appreciate the splendid help of Rheinbraun AG, who gave the permission for temperature measurements in a large number of their wells. The same for the N.V. Waterleiding Maatschapij Limburg/Maastricht, the Städtisches Umweltamt Aachen, and the Eschweiler Wasserverband. Two reviewers are acknowledged for many useful comments, helping to significantly improve the manuscript. Special thanks are due to Dipl. Phys. Harald Ührlings and Dr. Malte Ybs-von-Seht for their continuous help during the logging campaigns.

\section{References}

Balke, K.-D., 1970. Geothermische und Hydrogeochemische Anomalien im Erftgebiet.- Fortschr. Min., Beih. 2, S. 1-3, Stuttgart.

Balke, K.-D., 1973. Geothermische und hydrogeologische Untersuchungen in der südlichen Niederrheinischen Bucht. Geol. Jb. C5: $5-61$. 
De Braaf, W. \& Maas, W., 1952. Temperature Gradients in the South-Limburg Coal Field (The Netherlands). Geologie en Mijnbouw 14: 54-57.

Dornstätter, J. \& Sattel, G., 1985. Thermal Measurements in the research Borehole Konzen, Hohes Venn (West Germany).-N. Jb. Geol. Paläont. Abh., 171: 117-130, Stuttgart.

Dürbaum, J. \& Wolff, W., 1958. Das Schwerebild des südlichen Teils der Niederrheinischen Bucht. Fortschr. Geol. Rheinl. u. Westf. 2: 387-407.

Graulich, J.M., 1983. L'Hydrogéologie thermale de Chaudfontaine. Bull. Soc. Belge Géol. 92-3: 195 - 212.

Haenel, R., 1983. Geothermal Investigations in the Rhenish Massif. In: Fuchs, K, von Gehlen, K., Mälzer, H., Murawski, H., Semmel, H. (Eds): Plateau Uplift. Springer (Berlin, Heidelberg, New York, Tokyo).

Klett, M, Eichhorst, F. \& Schäfer, A., 2002. Facies interpretation from well logs applied to the Tertiary Lower Rhine Basin fill. Netherlands Journal of Geosciences/Geologie en Mijnbouw 81 (2): $167-176$.

Legrand, R., 1975. Jalons Géothermiques.-Toegelichte Verhandelingen voor de Geologische kaart en Mijnkaart van Belgie, 16, $1-46$, Bruxelles.

Mücke, G., 1964. Die Wärmeleitfähigkeit von Karbongesteinen und ihr Einfluss auf das Grubenklima. Bergbau-Archiv (Essen) 25 ?: 35-58.

Mücke, G., 1986. Gebirgstemperaturmessung, Zeche Sophia Jacoba, Bergbauforschung GmbH Essen, unpublished.

Pommerening, J., 1992. Hydrogeologie, Hydrogeochemie und Genese der Aachener Thermalquellen. Diss. RWTH Aachen (Aachen): $169 \mathrm{pp}$.

Ramaekers, J.J.F., 1991. The Netherlands. In: Hurtig, E., Cermak, V., Haenel, R. \& Zui, V. (Eds): Geothermal Atlas of Europe. Hermann Haack Verlagsgesellschaft mbH, Gotha.

Sadée, C.P.M., 1975. An Interpretation of South-Limburg Subsurface Temperature Data. Geologie en Mijnbouw 54: 184-194.

Schürmeyer, J., 1984. Bestimmung der Wärmeleitfähigkeit an Gesteinen des Salm (unteres Ordovizium) aus der Forschungsbohrung Konzen (nordöstliches Massiv von Stavelot-Venn) und ihre Korrelation mit geologischen und weiteren petrophysikalischen Parametern. Diplomarbeit RWTH Aachen, unpubl.

Schulz, R. \& Schellschmidt, R., 1991. Das Temperaturfeld im südlichen Oberrheingraben. Geol. Jb. E48: 153-165.

Spelter, M., 1978. Hydrogeologie, Hydrogeochemie und Hydrothermie der südlichen Niederrheinischen Bucht, insbesondere des Südteils der Erftscholle. Diss. RWTH Aachen (Aachen): $161 \mathrm{pp}$.

Van Balen, R.T., Verweij, J.M., Van Wees, J.D., Simmelink, H., Van Bergen, F. \& Pagnier, H., 2002. Deep subsurface temperatures in the Roer Valley Graben and the Peelblock, The Netherlands new results. Netherlands Journal of Geosciences/Geologie en Mijnbouw 81 (1): 19-26.

Van Dalfsen, H., 1981. Geothermal Investigation in shallow observation wells. Project G/A 9 - Contracts 073-76, The Shallow Subsurface Temperature Field in The Netherlands, Delft.

Vandenberghe, N. \& Fock, W., 1989. Temperature data in the subsurface of Belgium. Tectonophysics 164: 237-250.

Visser, W.A., 1978. Early subsurface temperature measurements in The Netherlands. Geologie en Mijnbouw 57: 1-10. 